\title{
The Quasi-biennial Oscillation and annual variations in tropical ozone from SHADOZ and HALOE
}

\author{
J. C. Witte ${ }^{1}$, M. R. Schoeberl ${ }^{2}$, A. R. Douglass ${ }^{2}$, and A. M. Thompson ${ }^{3}$ \\ ${ }^{1}$ Science Systems and Applications Inc., Lanham, Maryland, USA \\ ${ }^{2}$ NASA Goddard Space Flight Center, Greenbelt, Maryland, USA \\ ${ }^{3}$ Pennsylvania State University, University Park, Pennsylvania, USA \\ Received: 22 January 2008 - Published in Atmos. Chem. Phys. Discuss.: 27 March 2008 \\ Revised: 25 June 2008 - Accepted: 27 June 2008 - Published: 24 July 2008
}

\begin{abstract}
We examine the tropical ozone mixing ratio perturbation fields generated from a monthly ozone climatology using 1998 to 2006 ozonesonde data from the Southern Hemisphere Additional Ozonesondes (SHADOZ) network and the 13-year satellite record from 1993 to 2005 obtained from the Halogen Occultation Experiment (HALOE). The long time series and high vertical resolution of the ozone and temperature profiles from the SHADOZ sondes coupled with good tropical coverage north and south of the equator gives a detailed picture of the ozone structure in the lowermost stratosphere down through the tropopause where the picture obtained from HALOE measurements is blurred by coarse vertical resolution. Ozone perturbations respond to annual variations in the Brewer-Dobson Circulation (BDC) in the region just above the cold-point tropopause to around $20 \mathrm{~km}$. Annual cycles in ozone and temperature are well correlated. Above $20 \mathrm{~km}$, ozone and temperature perturbations are dominated by the Quasi-biennial Oscillation (QBO). Both satellite and sonde records show good agreement between positive and negative ozone mixing ratio anomalies and alternating QBO westerly and easterly wind shears from the Singapore rawinsondes with a mean periodicity of 26 months for SHADOZ and 25 months for HALOE. There is a temporal offset of one to three months with the QBO wind shear ahead of the ozone anomaly field. The meridional length scales for the annual cycle and the QBO, obtained using the temperature anomalies and wind shears in the thermal wind equation, compare well with theoretical calculations.
\end{abstract}

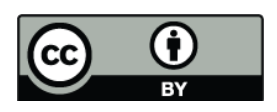

Correspondence to: J. C. Witte

(jacquelyn.c.witte@nasa.gov)

\section{Introduction}

One of the principal sources of interannual variability of the ozone distribution in the tropical mid-stratosphere is the quasi-biennial oscillation of the zonal wind (QBO). The QBO is characterized by downward propagation of alternating westerly and easterly wind regimes with a period varying from 20 months to 30 months (Reed et al., 1961). The QBO arises from the interaction of vertically propagating equatorial waves acting on the zonal mean flow (e.g., Baldwin et al., 2001 and references therein). The effect of the QBO can be seen on trace gases and temperature, both of which vary with the phase of the wind shear.

The Brewer-Dobson Circulation (BDC) also influences the tropical stratospheric circulation. The BDC is characterized by rising motion in the tropics from the troposphere into the stratosphere with poleward transport and descending motion in the stratosphere at middle and polar latitudes (Brewer, 1949; Dobson, 1956). Significant topographic differences between the northern and southern hemisphere change the wave activity and hence the strength of the BDC. These differences are apparent in the distribution of trace gases such as ozone (Fusco and Salby, 1999). The BDC varies annually and is stronger during northern hemisphere winter due to higher stratospheric wave activity.

We use the SHADOZ temperature profiles to develop a high vertical resolution tropical temperature perturbation time series. Using the temperature perturbations we can use the tropical thermal wind equation to compute the meridional length scales of the QBO and BDC, following the theoretical model of Plumb and Eluszkiewicz (1999).

Published by Copernicus Publications on behalf of the European Geosciences Union. 
Table 1. SHADOZ ozonesonde sites used in the study.

\begin{tabular}{lrrr}
\hline Tropical Sites & Lon (deg) & Lat (deg) & Study Years \\
\hline Ascension Island & -14.4 & -8.0 & $1999-2006$ \\
Heredia, Costa Rica & -84.1 & 10.0 & $2005-2006$ \\
Kuala Lumpur, Malaysia & 101.7 & 2.73 & $1998-2006$ \\
Malindi, Kenya & 40.2 & -3.0 & $1999-2006$ \\
Nairobi, Kenya & 36.8 & -1.3 & $1998-2006$ \\
Natal, Brazil & -35.4 & -5.4 & $1999-2006$ \\
Paramaribo, Surinam & -55.2 & 5.8 & $1999-2006$ \\
San Cristóbal, Equador & -89.6 & -0.9 & $1998-2006$ \\
Watukosek-Java, Indonesia & 112.7 & -7.6 & $1998-2006$ \\
\hline
\end{tabular}

Previous work by Logan et al. (2003) used individual tropical ozone data from the SHADOZ network to map the changes in the shape of the ozone profiles induced by the QBO winds. Using almost four years of SHADOZ sounding data (late 1997 to early 2001) from three southern hemisphere stations, they showed a coherent relationship between the zonal winds and observed tropical ozone. Logan et al. (2003) expanded their study to examine the sub-tropical morphology of the QBO signal outside 20 degrees of the equator and the strong El Nino Southern Oscillation (ENSO) event in 1997-1998. At the time of the Logan et al. (2003) study, only four years of ozonesonde data had been archived from the southern equatorial region and the goal was to study two complete QBO cycles where one cycle could be effected by the ENSO signal. The present study considers all SHADOZ stations within 10 degrees north and south of the equator. At present, there are nine years of ozonesonde data allowing us to capture roughly four complete QBOs and nine annual cycles. In addition, we analyze stratospheric ozone profiles from 1993-2005 obtained from the Halogen Occultation Experiment (HALOE), one of the sensors on the Upper Atmosphere Research Satellite (Reber et al., 1993).

In this study, the data are described in the following section. The analysis given in Sect. 3 includes three components: the morphology of the ozone and temperature anomalies in the QBO regime (Sect. 3.1); the annual variations of ozone and temperature (Sect. 3.2); and estimates of the length scales of the annual cycle and the QBO using the power spectrum of temperature and wind shear (Sect. 3.3). A summary follows in Sect. 4.

\section{Data}

All SHADOZ stations use balloon-borne Electrochemical Concentration Cell (ECC) ozonesondes (Komhyr, 1995), except Watukosek-Java, which had used Meisei RSII-KC79D soundings prior to August 1999 (Kobayashi et al., 1966). The ozonesonde instrument is coupled with a radiosonde that measures pressure, temperature and relative humidity at 1 to

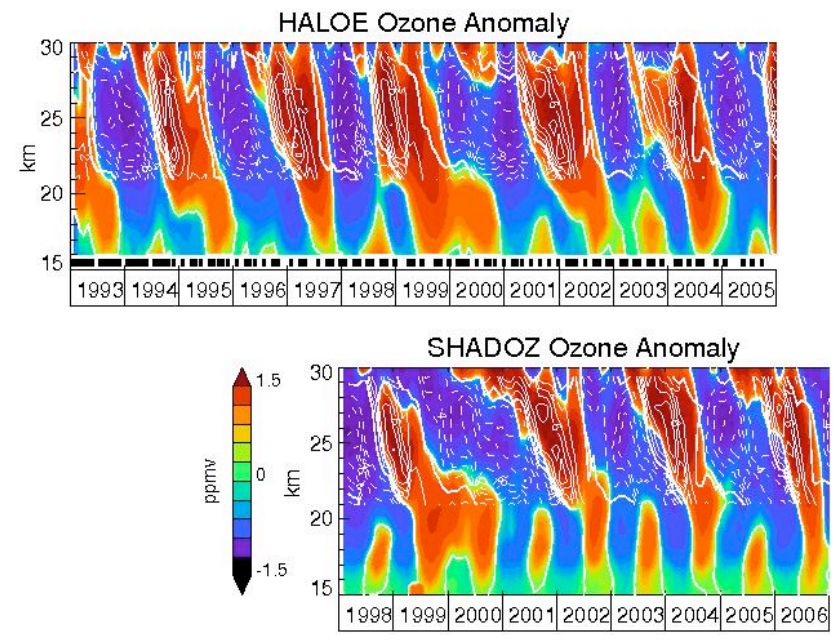

Fig. 1. Time series curtain plot of ozone mixing ratio anomalies (ppmv) using HALOE (top panel) and SHADOZ (bottom panel) data records. Bold white contour indicates the zero level between positive anomalies (red) and negative anomalies (blue). Overlaid are white lined contours of the QBO wind shear $(\mathrm{m} / \mathrm{s} / \mathrm{km})$. Solid lines indicate positive wind regime and dashed lines indicate negative wind regime. The zero contour of the wind shear data is plotted as the extra-thick white line. Black bars in the top panel for HALOE indicate where data are available.

10-s intervals. The ECC ozonesonde measures ozone up to $33 \mathrm{~km}$ with 5\% instrument precision (Thompson et al., 2003) and vertical resolution between 5 and $50 \mathrm{~m}$, allowing us to resolve features in tropical ozone variability related to climate and dynamics. Detailed precision and performance assessments are given by Johnson et al. (2002) and Smit et al. (2007) and references therein.

The ozone and temperature perturbation fields have been generated from nine years of SHADOZ data (1998 to 2006) confined to stations located within a $10^{\circ} \mathrm{N}-10^{\circ} \mathrm{S}$ latitude range. The ozone QBO signal is strongest and most evident within that equatorial band (e.g., Baldwin et al., 2001; Dunkerton, 2001); the results of the analyses do not change when we further limit the dataset to within five degrees of the equator. Table 1 lists the nine tropical sites from the SHADOZ record used in this study where over 2000 profiles were used. Thompson et al. $(2003 ; 2007)$ provides documentation of each station's instrumentation and launch procedures.

Ozone profiles from the Halogen Occultation Experiment (HALOE) complement the SHADOZ ozone record. This study analyzes 13 years of the HALOE ozone record from 1993-2005 (Russell et al., 1993; Brühl et al., 1996) using zonal monthly means at the equator that have been constructed by Schoeberl et al. (2008) at a vertical resolution close to $2 \mathrm{~km}$. HALOE is a solar occultation instrument viewing, on average, 15 sunrises and sunsets daily over a narrow latitudinal range. Global sampling requires approximately 30 days. 


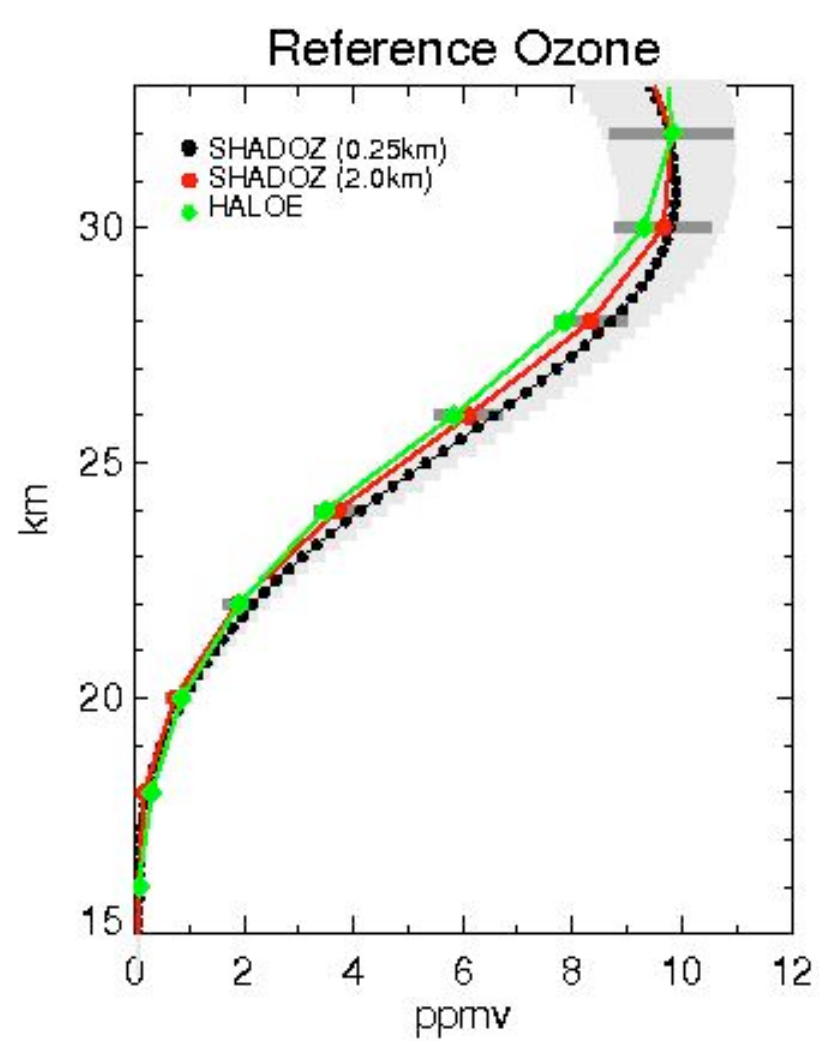

Fig. 2. SHADOZ and HALOE reference profiles of ozone mixing ratio (ppmv). SHADOZ profiles are plotted at vertical resolutions of $2.0 \mathrm{~km}$ (solid red circle) to match HALOE (solid green diamond) and $0.25 \mathrm{~km}$ (solid black circle). The gray shading indicates the 1sigma from the $2.0 \mathrm{~km}$ (dark gray) and $0.25 \mathrm{~km}$ (light gray) mean. The HALOE reference profile is calculated from 1998 to 2005 to match the SHADOZ years.

Time series of the monthly mean ozone and temperature anomalies are produced by taking the monthly averaged profiles and subtracting the average of the same month for all nine years (e.g., January 2000 minus the January climatology from the dataset). The ozonesonde profiles have been averaged and interpolated to a uniform $0.25 \mathrm{~km}$ vertical grid. Gaps in the HALOE record have been linearly interpolated using adjacent values. The anomaly fields from SHADOZ have no gaps in time and altitude, and thus no additional interpolation is required.

In the analysis section below, the ozone and temperature perturbation fields are compared with the monthly zonal mean wind shear calculated from the Singapore rawinsonde wind fields (Naujokat, 1986). Wind observations from $50 \mathrm{hPa}(19 \mathrm{~km})$ to $15 \mathrm{hPa}(30 \mathrm{~km})$ are used. The monthly zonal wind shear dataset was constructed by taking the vertical derivative of the monthly zonal mean winds.

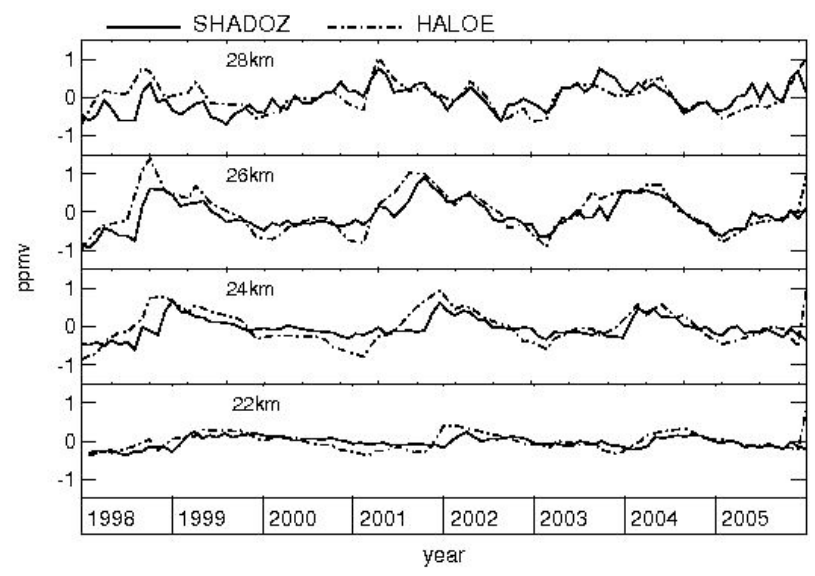

Fig. 3. Monthly time series of ozone anomalies (ppmv) for SHADOZ (solid) and HALOE (dashed) at various altitude levels that are limited to the HALOE vertical resolution $(2 \mathrm{~km})$.

\section{Analysis}

\subsection{QBO morphology of ozone and temperature}

Figure 1 shows a time-height section of monthly mean perturbation ozone mixing ratio for HALOE (top panel) and SHADOZ (bottom panel). Superimposed is the zonal mean wind shear component of the Singapore winds. The satellite/sonde reference profiles of ozone are shown in Fig. 2 and represent the mean of all profiles within the SHADOZ time period. Above $22 \mathrm{~km}$ the ozone reference profiles are in close agreement when the sonde vertical resolution is degraded to $2 \mathrm{~km}$ (solid red circle) to match HALOE. Otherwise, HALOE apparently underestimates the sondes at the higher vertical resolution (black solid circle) by as much as 1 ppmv. HALOE and SHADOZ ozone time series at various altitudes from 1998-2005 are in qualitative agreement (Fig. 3). At the heights of interest, the two records track each other despite the differing measurement resolutions and interpolation in the HALOE record for missing months (see gaps between the black bar symbols in Fig. 1).

Both records in Fig. 1 show the effect of a strong QBO signal on the ozone field above $20 \mathrm{~km}$ as descending positive and negative ozone anomalies exhibit similar patterns as the wind shear (white contours). The ozone anomaly field maximizes around $25-27 \mathrm{~km}$ with gradual attenuation of the signal as it descends to $20 \mathrm{~km}$ and transitions to a strong annual cycle. The ozone anomalies range \pm 1.4 ppmv in the vicinity of the maximum perturbations. In the vertical, the locations of the maximum zonal wind shear tend to be co-located with the highest ozone concentrations. However, the maxima are not contemporaneous. Linear correlation coefficients of ozone anomalies and wind shear were computed at heights within the dominant QBO regime (within $20 \mathrm{~km}$ to $30 \mathrm{~km}$ ) for a range of time lags from -5 to +5 months. The best fits 
Table 2. Correlation coefficients $\left(r^{2}\right)$ and lag offset in months between the zonal mean wind shear and the SHADOZ and HALOE ozone perturbations.

\begin{tabular}{lcccc}
\hline & \multicolumn{2}{c}{$r^{2}$} & \multicolumn{2}{c}{ Lag (Months) } \\
\cline { 2 - 5 } Altitude & SHADOZ & HALOE & SHADOZ & HALOE \\
\hline $22.5 \mathrm{~km}$ & 0.67 & 0.70 & +3 & +2 \\
$24.5 \mathrm{~km}$ & 0.81 & 0.84 & +3 & +1 \\
$27.5 \mathrm{~km}$ & 0.79 & 0.73 & +1 & -1 \\
\hline
\end{tabular}

Table 3. Same as Table 2 except wind shear is correlated with the SHADOZ temperature perturbations.

\begin{tabular}{ccc}
\hline Altitude & $r^{2}$ & Lag (Months) \\
\hline $22.5 \mathrm{~km}$ & 0.57 & +2 \\
$25.5 \mathrm{~km}$ & 0.70 & +2 \\
$27.5 \mathrm{~km}$ & 0.73 & 0 \\
\hline
\end{tabular}

are summarized in Table 2, where positive correlations show the zonal wind shear preceding the ozone anomalies by one to three months. Using Fig. 1 as a visual guide, we can interpret the temporal variability in ozone anomalies as increasing (decreasing) after the passage of the maximum easterly (westerly) shear. The exception is at $27.5 \mathrm{~km}$, where Table 2 shows the lag switching sign with the HALOE ozone anomalies preceding the zonal wind shear by one month. There is a slight tendency for the QBO wind shear and ozone to be synchronized with height as the lags decrease with increasing height (Table 2) and the timing of descent of the shear zone coincides with the largest ozone anomalies (Fig. 1). Around this level and above, the ozone concentrations reach peak values and respond more rapidly to shifts in the wind field. The vertical gradient of the reference profiles, calculated from Fig. 2, confirm a peak at around $26 \mathrm{~km}$ with an amplitude of $1.15 \mathrm{ppmv} / \mathrm{km}$.

A strong ENSO event peaked in the latter half of 1997 and continued through early 1998. Logan et al. (2003) attributed the influence of the ENSO to an apparent anti-correlation between the QBO wind shear and ozone anomalies from the Nairobi, Kenya ozonesondes and SAGE II data below $40 \mathrm{hPa}$ $(\sim 22 \mathrm{~km})$. The ozone anomalies from our tropical climatology below $22 \mathrm{~km}$ do not show this relationship in 1998 or any other year. The zonal averaging of the SHADOZ data diminishes any ENSO signal that is known to be very weak compared to the QBO and annual cycles (Hamilton et al., 2003). HALOE does not retrieve data at a high enough vertical resolution to isolate such an effect. In addition, there is a time lag between both ozone datasets and the QBO winds that might explain the anti-correlation as merely a temporal shift between the wind shear zones and the localized ozone anomalies. The ENSO signal is not considered further in this study.

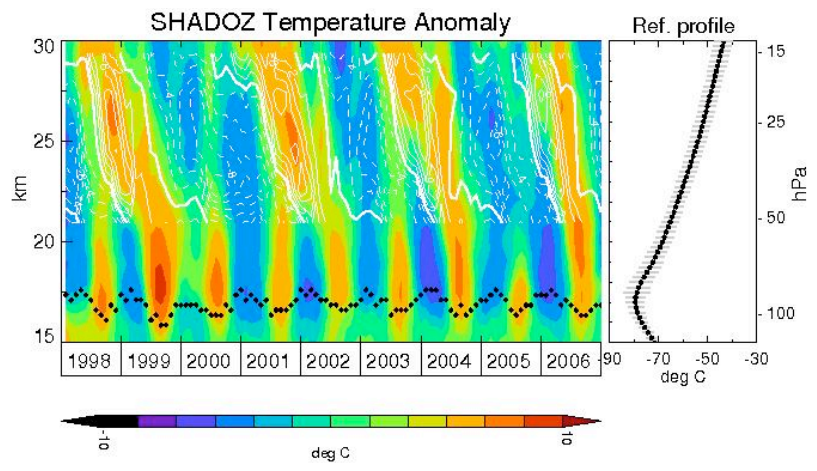

Fig. 4. Monthly time series curtain plot of ozonesonde temperature anomalies (degree C) with overlaid lined contours of QBO wind shear $(\mathrm{m} / \mathrm{s} / \mathrm{km})$ in white, as in Fig. 1. Filled black diamonds are the mean monthly cold point tropopause heights. Right panel is a plot of the reference temperature profile. Gray shading indicates the one-sigma deviation from the mean.

The time evolution of the SHADOZ temperature perturbation field is shown in Fig. 4 with contours of wind shear superimposed. The structure of the temperature anomaly time series closely resembles that of the ozone anomalies seen in Fig. 1, and the temperature anomalies and wind shear are closely synchronized as expected from the thermal wind balance relationship (see Andrews et al., 1987; Eq. 8.2.2; Randel et al., 1999; Baldwin et al., 2001). In the QBO region between $20 \mathrm{~km}$ and $30 \mathrm{~km}$, the zones of westerly (easterly) wind shear correspond to regions of positive (negative) temperature anomalies. The maximum anomaly in the temperature signal is between $25 \mathrm{~km}$ and $27 \mathrm{~km}$, similar to the location of the maximum ozone anomaly. The amplitude of the temperature anomaly is $\pm 6 \mathrm{~K}$. The exception is in the latter half of 2005 into 2006 where the maximum amplitudes of the zonal wind shear and temperature anomaly above $25 \mathrm{~km}$ are not well aligned. We attempted to resolve this offset by removing the linear trend in the temperature anomaly but the result showed only a marginal improvement in the agreement with the QBO wind shear. Correlation estimates summarized in Table 3 show no apparent lag above $25 \mathrm{~km}$. Below $25 \mathrm{~km}$ the temperature phase change lags the $\mathrm{QBO}$ wind shear phase change by two months.

\subsection{Annual cycles in ozone and temperature}

At $20 \mathrm{~km}$ and below the SHADOZ record captures welldefined annual variations in ozone (Fig. 1, bottom panel) and temperature (Fig. 4) related to the annual variations in the BDC. When we degrade the vertical resolution of the SHADOZ profiles to $2 \mathrm{~km}$, and recalculate the ozone anomaly time series, the resulting morphology below $20 \mathrm{~km}$ is similar to that of HALOE (not shown). Here, the advantage of using ozonesonde data is that we can resolve vertical structures that cannot be seen by remote sensing techniques. 


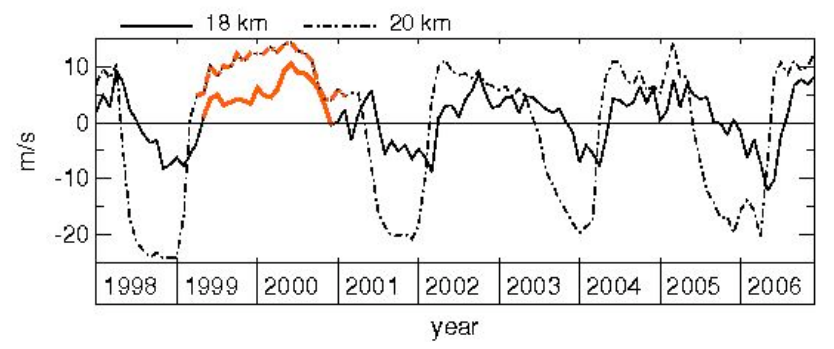

Fig. 5. QBO zonal mean winds $(\mathrm{m} / \mathrm{s})$ at $18 \mathrm{~km}$ (solid) and $20 \mathrm{~km}$ (dashed). Red lines highlight the lengthy time period where positive westerly wind shear sustains positive ozone and temperature anomalies.

Between $15 \mathrm{~km}$ and $20 \mathrm{~km}$ the ozone anomaly concentrations range from $-0.17 \mathrm{ppmv}$ to $+0.66 \mathrm{ppmv}$ in the SHADOZ record, with slightly smaller amplitudes from HALOE. The annual signal in the temperature anomaly field is slightly stronger than the QBO signal with amplitudes ranging $\pm 8 \mathrm{~K}$. The cold-point tropopause heights (Fig. 4, filled diamonds) typically occur within $16 \mathrm{~km}$ and $17.5 \mathrm{~km}$ and undulate along the base of the annual signal at levels where the gradients of the temperature anomalies start to amplify. Below the tropopause, located on average at around $16 \mathrm{~km}$, the annual amplitudes of the ozone and temperature perturbations weaken rapidly. Using the SHADOZ sondes Randel et al. (2007) pointed out that annual variations in tropopause ozone are more likely to be caused by the annual variations in the $\mathrm{BDC}$ acting on the time mean ozone gradient rather than annual variations in convective lofting (Folkins et al., 2006). Figures 1 and 4 support the BDC forcing idea since convective lofting would not produce larger anomalies at $16 \mathrm{~km}$ than below.

In the transition region from $16 \mathrm{~km}$ to $20 \mathrm{~km}$, Figs. 1 and 4 show the interaction between the annual variations in the $\mathrm{BDC}$ and the QBO acting on the ozone and temperature concentrations. The BDC upwelling is stronger during the Northern Hemisphere winter due to stratospheric wave driving (Haynes et al., 1991; Waugh, 1993; Randel et al., 1993; Schoeberl et al., 2008). In the case where the QBO and the BDC are in phase, the QBO signal appears to descend to the tropopause, as positive ozone anomalies of both systems merge, as previously noted by Gray and Dunkerton (1990). When the QBO easterly wind shear regime (Figs. 1 and 4 , negative dashed contours) descends, negative ozone anomalies (blue contours) are met by the BDC positive ozone anomalies splitting the QBO feature. Interestingly, during the SHADOZ time period we observe an unusually large cell of positive ozone and temperature anomalies in the region of the annual cycle that extends from 1999 into 2000 in Figs. 1 and 4. Figure 5 reveals a broad region of persistent QBO westerly winds modifying the annual cycle by sustaining higher temperatures, allowing the ozone anomaly to grow and be maintained over the two year period.

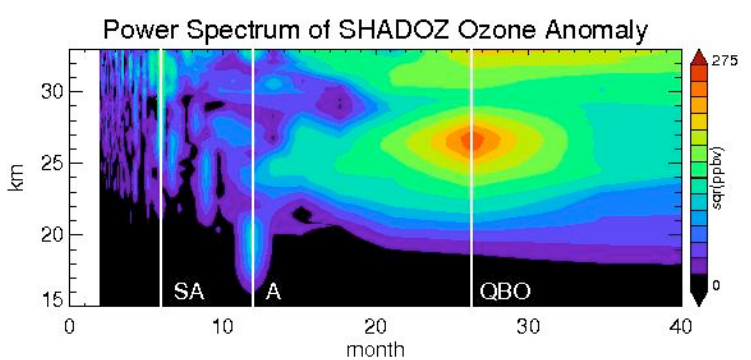

(a)

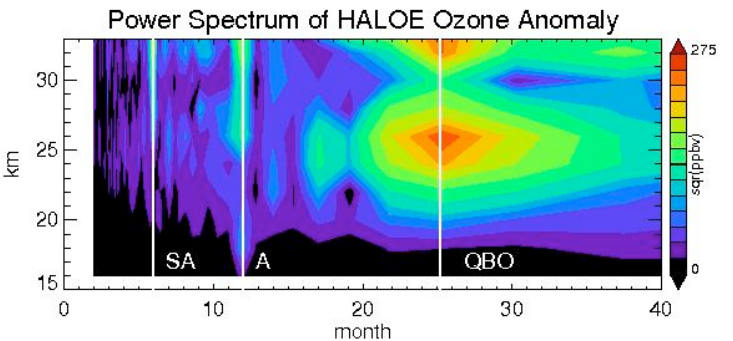

(b)

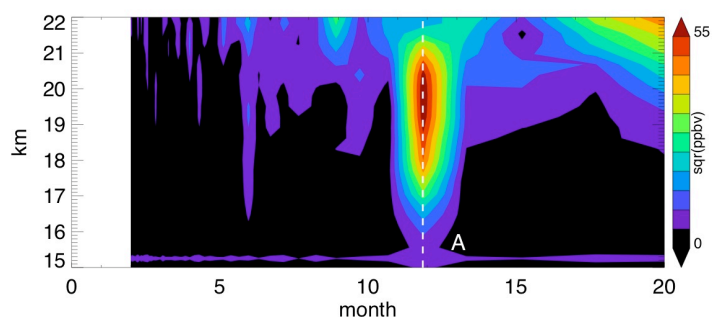

(c)

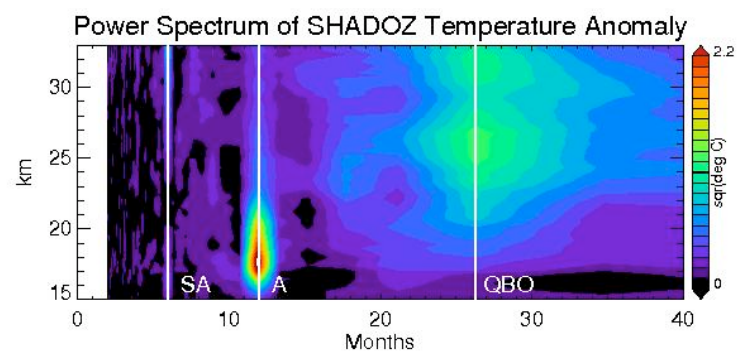

(d)

Fig. 6. Power spectrum of (a) SHADOZ and (b) HALOE tropical ozone mixing ratio anomaly field $\left(\mathrm{ppbv}^{2}\right.$ ) versus period in months, (c) same as (a) but a close-up of the annual amplitudes, and (d) SHADOZ temperature anomaly $\left({ }^{\circ} \mathrm{C}^{2}\right)$. White vertical lines mark the semi-annual, annual, and the QBO periods and are notated by "SA", "A", and "QBO", respectively.

\subsection{Ozone periodicity and length scales}

The SHADOZ and HALOE ozone power spectrum in Figs. 6a and b, respectively, reveal a broad maximum range of amplitudes in the QBO signal that peaks between $25 \mathrm{~km}$ and $27 \mathrm{~km}$ with a periodicity centered around 26 months for SHADOZ and 25 months for HALOE. Here, the ozone 


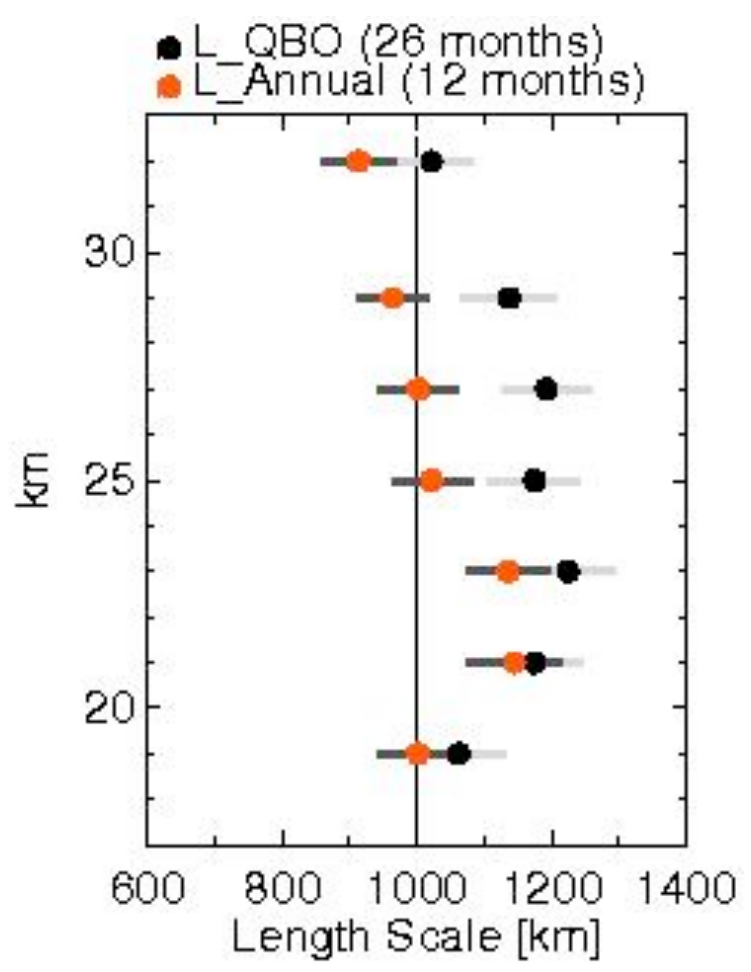

Fig. 7. (black circles) and BDC annual (red squares) length scales at the vertical resolution the QBO winds. The $1000 \mathrm{~km}$ length scale is marked. A parametric bootstrap technique estimates the standard deviation of the length scales (gray lines) using a 5\% instrument error in the ozonesonde temperature measurements and rawinsondes wind measurements.

anomaly reaches a maximum amplitude of around $15 \mathrm{ppbv}$. There is a secondary QBO peak above $33 \mathrm{~km}$ measured in both records; however, there is less certainty about the ozone measurement accuracy at those levels. The ozone annual cycle at twelve months is also visible with a narrow maximum below around $20 \mathrm{~km}$ in both records. Also evident is the semi-annual oscillation above $30 \mathrm{~km}$. The annual signal in the ozone anomaly is modest compared to that of the QBO signal that is pervasive above $20 \mathrm{~km}$. In Fig. 6c, we zoomedin to isolate the annual signal using the SHADOZ ozone anomaly record to illustrate a narrow peak from $17 \mathrm{~km}$ to $21 \mathrm{~km}$ with a maximum value of around $7.4 \mathrm{ppbv}$. Similarly, HALOE records a maximum annual amplitude of around $6.3 \mathrm{ppbv}$ in the ozone anomaly field (not shown). A similar frequency distribution in the temperature spectrum is shown in Fig. 6d where the annual cycle is particularly prominent compared to the QBO signal that is similarly broad but weaker in amplitude. The maximum amplitudes of the annual and QBO temperature signals are $1.5^{\circ} \mathrm{C}$ and $0.53^{\circ} \mathrm{C}$, respectively.

From Fig. 4 we observe a coherent relationship between the temperature anomalies and the zonal mean wind shear. Quantitatively, this close relationship can be represented by the thermal wind equation where we assume latitudinal sym- metry about the equator. Using notation from Baldwin et al. (2001), the thermal wind equation in the tropics can expressed as $\frac{\partial \bar{u}}{\partial z}=\frac{R \bar{T}}{H \beta L^{2}}$ where $\partial \bar{u} / \partial z$ is the zonal mean wind shear $(\mathrm{m} / \mathrm{s} / \mathrm{km}), R$ is the dry air gas constant, $\bar{T}$ is the zonal mean temperature anomaly, $L$ is the length scale, $H$ is the scale height $(\sim 7 \mathrm{~km})$, and $\beta$ is the latitudinal derivative of the Coriolis parameter at the equator. Using the amplitudes of the power spectrum we can extract the vertical profiles of the SHADOZ temperature anomalies (Fig. 6d) and the zonal mean wind shear (not shown) at the periods of 12 and 26 months to derive the QBO and BDC length scales, respectively. Figure 7 shows the profiles of the QBO and BDC length scales, respectively. Where the QBO temperature anomaly dominates above $20 \mathrm{~km}$, our analysis shows that the QBO width is between $1000 \mathrm{~km}$ and $1200 \mathrm{~km}$, as also found by Randel et al. (1999). The BDC length scales derived here vary from $1150 \mathrm{~km}$ at $21 \mathrm{~km}$ to near $1000 \mathrm{~km}$ at $29 \mathrm{~km}$. Plumb and Eluszkiewicz (1999) modeled upwelling length scales of the BDC on either side of the equator and estimate a theoretical length scale of roughly $1100 \mathrm{~km}$ between $15 \mathrm{~km}$ and $25 \mathrm{~km}$, similar to the range we derive from observations.

\section{Summary}

Our study takes advantage of the long-term ozone and temperature record from the SHADOZ ozonesonde network and ozone retrievals from HALOE along the tropical band to construct a time series of ozone and temperature anomalies. With the high vertical resolution in-situ sounding data in the tropics we developed a detailed picture of the ozone vertical anomalies near the equator at resolutions greater than satellite retrievals. The SHADOZ observations show that below $35 \mathrm{~km}$ most of the variability in tropical ozone and temperature are due to the QBO-induced circulation that sits atop the annual variations in the BDC. Between the tropopause and $20 \mathrm{~km}$ variations in ozone and temperature are controlled by the annual cycle in the BDC (Randel et al., 2007). The ozone anomalies from the SHADOZ ozonesonde dataset agree with the zonal wind shear better than those obtained using HALOE profiles, and the structure of the annual variations in ozone and temperature below $20 \mathrm{~km}$ are more refined. The annual signals in the ozone fields maximize at the tropopause implying that convection alone cannot produce the large annual tropopause anomalies in ozone, also noted by Randel et al. (2007).

From our results, we conclude that the ozone and temperature anomalies are controlled primarily by the wave meanflow interactions of the BDC annual cycles. Correlations between the ozone and temperature tracer fields with the QBO winds show close agreement with maximum amplitudes between $25 \mathrm{~km}$ and $27 \mathrm{~km}$. The temporal offset is one to three months with the QBO ozone and temperature changing sign after the passage of the shear zones. The periodicity 
is similar to other studies at 25 to 26 months. The periodic irregularity indicates that the QBO behavior is primarily driven by internal wave dynamics rather than other periodic oscillations, such as seasonal or solar cycles. The interaction between the QBO and annually varying BDC signals is evident in the transition zone between the tropopause and the lowermost stratosphere $(16 \mathrm{~km}-20 \mathrm{~km})$. When the QBO and Brewer-Dobson anomalies are in phase the positive ozone anomaly extends past the tropopause $(\sim 16 \mathrm{~km})$. Conversely, when out-of-phase the QBO-induced negative ozone anomalies associated with the easterly regime extend to the tropopause.

The meridional width of the QBO component is in good agreement with results by Randel et al. (1999). The QBO length scale increases with height and is approximately $1200 \mathrm{~km}$ on either side of the equator in the mid-stratosphere. For the first time, we can also assess the meridional extent of the annual BDC cycle using the frequency distribution of the temperature observations from ozonesondes across the tropics. The results show a mean length scale close to $1000 \mathrm{~km}$, consistent with earlier theoretical estimates by Plumb and Eluszkiewicz (1999).

Acknowledgements. This work is supported by the NASA Atmospheric Chemistry Modeling and Analysis Program (ACMAP).

Edited by: M. Dameris

\section{References}

Baldwin, M. P., Gray, L. J., Dunkerton, T. J., Hamilton, K., et al.: The Quasi-Biennial Oscillation, Rev. of Geophys., 39, 179-230, 2001.

Brewer, A. M.: Evidence for a world circulation provided by the measurements of helium and water vapor distribution in the stratosphere, Quart. J. Roy. Meteorol. Soc., 75, 351-363, 1949.

Brühl, C., Drayson, S. R., Russell, J. M., Crutzen, P. J., et al.: Halogen Occultation Experiment ozone channel validation, J. Geophys. Res., 101, 10 217-10 240, 1996.

Dobson, G. M. B.: Origin and Distribution of the Polyatomic Molecules in the Atmosphere, Proc. Roy. Soc., A236, 187-193, 1956.

Dunkerton, T. J.: Quasi-biennial and subbiennial variations of stratospheric trace constituents derived from HALOE observations., J. Atmos. Sci., 58, 7-25, 2001.

Folkins, I., Bernath, P., Boone, C., Thompson, A. M., Walker, K., and Witte, J. C.: Seasonal cycles of $\mathrm{O}_{3}$, $\mathrm{CO}$ and convective outflow at the tropical tropopause, Geophys. Res. Lett., 33, L16802, doi:10.1029/2006GL026602, 2006.

Fusco, A. C. and Salby, M. L.: Interannual variations of total ozone and their relationship to variations of planetary wave activity, J. Climate, 12, 1619-1629, 1999.

Gray, L. J. and Dunkerton, T. J.: The role of the seasonal cycle in the Quasi-biennial Oscillation of ozone, J. Atmos. Sci., 47, 2429-2451, 1990.

Hamilton, K.: Interannual variability in the Northern Hemisphere winter middle atmosphere in control and perturbation experi- ments with the GFDL SKYHI general circulation model, J. Atmos. Sci., 52, 44-66, 1994.

Haynes, P. H., Marks, C. J., McIntyre, M. E., Shepherd, T. G., and Shine, K. P.: On the "downward control" of extratropical diabatic circulations by eddy-induced mean zonal forces, J. Atmos. Sci., 48, 651-678, 1991.

Johnson, B. J., Oltmans, S. J., Vömel, H., Smit, H. G. J., Deshler, T., and Kröger, C.: Electrochemical concentration cell (ECC) ozonesonde pump efficiency measurements and tests on the sensitivity to ozone of buffered and unbuffered ECC sensor cathode solutions, J. Geophys. Res., 107, 4393, doi:10.1029/2001JD000557, 2002.

Kiehl, J. T. and Solomon, S.: On the radiative balance of the stratosphere, J. Atmos. Sci., 43, 1525-1534, 1986.

Kobayashi, J. and Toyama, Y.: On various methods of measuring the vertical distribution of atmospheric ozone (III) carbon-iodine type chemical ozonesonde, Pap. Meteorol. Geophys., 17, 113126, 1966.

Komhyr, W. D., Barnes, R. A., Brothers, G. B., Lathrop, J. A., and Opperman, D. P.: Electrochemical concentration cell ozonesonde performance evaluation during STOIC 1989, J. Geophys. Res., 100, 9231-9244, 1995.

Logan, J. A., Jones, D. B. A., Megretsjaia, I. A., Oltmans, S. J., Johnson, B. J., Vömel, H., Randel, W. J., Kimani, W., and Schmidlin, F. J.: Quasibiennial oscillation in tropical ozone as revealed by ozonesonde and satellite data, J. Geophys. Res., 108, 4244, doi:10.1029/2002JD002170, 2003.

Naujokat, B.: An update of the observed quasi-biennial oscillation of the stratospheric winds over the Tropics, J. Atmos. Sci., 43, 1873-1877, 1986.

Plumb, R. A. and Eluszkiewicz, J.: The Brewer-Dobson Circulation: Dynamics of the Tropical Upwelling, J. Atmos. Sci., 56, 868-890, 1999.

Randel, W. J., Gille, J. C., Roche, A. E., Kumer, J. B., Mergenthaler, J. L., Waters, J. W., Fishbein, E. F., and Lahoz, W. A.: Stratospheric transport from the tropics to middle latitudes by planetary-wave mixing, Nature, 365, 533-535, 1993.

Randel, W. J., Wu, F., Swinbank, R., Nash, J., and O'Neill, A.: Global QBO circulation derived from UKMO stratospheric analyses, J. Atmos. Sci., 56, 457-474, 1999.

Randel, W. J., Park, M., Wu, F., and Livesey, N.: A large annual cycle in ozone above the tropical tropopause linked to the BrewerDobson circulation, J. Atmos. Sci., 64, 4479-4488, 2007.

Reber, C. A., Trevathan, C. E., McNeal, R. J., and Luther, M. R.: The Upper Atmosphere Research Satellite (UARS) mission, J. Geophys. Res., 98, $10643-10$ 647, 1993.

Reed, R. J., Campbell, W. J., Rasmussen, L. A., and Rogers, R. G.: Evidence of a downward propagating annual wind reversal in the equatorial stratosphere, J. Geophys. Res., 66, 813-818, 1961.

Russell, J. M., Gordley, L. L., Park, J. H., Drayson, S. R., Hesketh, W. D., Cicerone, R. J., Tuck, A. F., Frederick, J. E., Harries, J. E., and Crutzen, P. J.: The Halogen Occultation Experiment, J. Geophys. Res., 98, 10777-10 797, 1993.

Schoeberl, M. R., Douglass, A. R., Newman, P. A., Lait, L. R., Lary, D., Waters, J., Livesey, N., Froidevaux, L., Lambert, A., Read, W., Filipiak, M. J., and Pumphery, H. C.: QBO and annual cycle variations in tropical lower stratosphere trace gases from HALOE and Aura MLS observations, J. Geophys. Res., 113, D05301, doi:10.1029/2007JD008678, 2008. 
Smit, H. G. J., Straeter, W., Johnson, B. J., Oltmans, S. J., et al.: Assessment of the performance of ECC-ozonesondes under quasi-flight conditions in the environmental simulation chamber: insights from the Juelich Ozone Sonde Intercomparison Experiment (JOSIE), J. Geophys. Res., 112, D19306, doi:10.1029/2006JD007308, 2007.

Thompson, A. M., Witte, J. C., McPeters, R. D., Oltmans, S. O., et al.: Southern Hemisphere Additional Ozonesondes (SHADOZ) 1998-2000 tropical ozone climatology - 1: Comparison with Total Ozone Mapping Spectrometer (TOMS) and ground-based measurements, J. Geophys. Res., 108, 8238, doi:10.1029/2001JD000967, 2003.
Thompson, A. M., Witte, J. C., Smit, H. G. J., Oltmans, S. J., Johnson, B. J., Kirchhoff, V. W., and Schmidlin, F. J.: Southern Hemisphere ADditional Ozonesondes (SHADOZ) 1998-2004 tropical ozone climatology - 3: Instrumentation, station-to-station variability, and evaluation with simulated flight profiles, J. Geophys. Res., 112, D03304, doi:10.1029/2005JD007042, 2007.

Waugh, D. W.: Subtropical stratospheric mixing linked to disturbances in the polar vortices, Nature, 365, 535-537, 1993. 